\title{
DETERMINAN PENYAKIT KULIT PADA PEMULUNG DI TPA TELAGA PUNGGUR
}

\author{
M. Kafit, Herdianti ${ }^{\varpi}$, Zahara Gema Gatra \\ Fakultas Ilmu Kesehatan Universitas Ibnu Sina Batam
}

\begin{tabular}{l}
\hline ARTICLE INFO \\
\hline Article history \\
Submitted : 2020-07-27 \\
Revised : 2021-06-02 \\
Accepted : 2021-07-10 \\
\hline Keywords: \\
Dermatitis \\
Personal hygiene \\
Personal protective
\end{tabular}

\section{Kata Kunci:}

Penyakit kulit

Higiene perorangan Alat Pelindung Diri

\begin{abstract}
Dermatitis is a disease that attacks the skin on the surface of the body which is commonly found among residents in hot, humid climates, poor personal hygiene, poor environment, and workers who deal with dirt (e.g. garbage and sewers). This study aimed to determine the relationship between personal hy giene and the use of PPE for scavengers with skin diseases at the TPA Telaga Punggur, Batam City. The method used was descriptive quantitative using a cross-sectional study design. The population in this study were all scavengers in TPA Telaga Punggur as many as 791 scavengers and as many as 89 scavengers who were sampled by purposive sampling technique. The results showed that $75.3 \%$ had poor personal hy giene and $73.0 \%$ did not wear PPE when working, and $70.8 \%$ had skin diseases. There is a relationship between personal hy giene $(\mathrm{p}=0.006)$ and the use of PPE $(\mathrm{p}=0.000)$ with the incidence of skin disease at Telaga Punggur landfill. Scavengers are expected to pay attention to clean and healthy living behavior by maintaining personal hygiene and always using personal protective equipment when working.

$\overline{\text { Penyakit kulit merupakan suatu penyakit yang menyerang kulit permukaan tubuh yang }}$ banyak ditemukan di kalangan penduduk di daerah beriklim panas, lembap keadaan perorangan yang kurang hygiene, lingkungan yang buruk dan pekerja-pekerja yang berhubungan dengan kotoran (misalkan sampah dan selokan). Penelitian ini bertujuan untuk mengetahui hubungan Higiene perorangan dan Pemakaian APD pemulung dengan penyakit kulit di TPA Telaga Punggur Kota Batam. Metode yang digunakan adalah deskriptif kuantitatif dengan menggunakan rancangan cross sectional study. Populasi dalam penelitian ini seluruh pemulung di TPA Telaga Punggur sebanyak 791 pemulung dan sebanyak 89 pemulung yang menjadi sampel dengan teknik purposive sampling. Hasil penelitian menunjukkan terdapat $75,3 \%$ memiliki higiene perorangan yang buruk dan 73,0\% tidak memakai APD saat bekerja dan 70,8\% mengalami peny akit kulit. Ada hubungan antara Higiene perorangan $(\mathrm{p}=0,006)$ dan pemakaian APD $(\mathrm{p}=$ 0,000) dengan kejadian penyakit Kulit TPA Telaga Punggur. Diharapkan pemulung untuk memperhatikan perilaku hidup bersih dan sehat dengan cara menjaga kebersihan diri dan selalu menggunakan alat pelindung diri saat bekerja.
\end{abstract}

$\triangle$ Corresponding Author:

Herdianti

Fakultas Ilmu Kesehatan Universitas Ibnu Sina Batam

Telp. 085395925901

Email: herdianti@uis.ac.id

\section{PENDAHULUAN}

Usaha peningkatan kesehatan lingkungan yang umumnya dikenal dengan sebutan sanitasi menurut World Health Organisation (WHO) adalah suatu usaha yang mengawasi beberapa faktor lingkungan fisik yang berpengaruh kepada manusia terutama terhadap hal-hal yang mempengaruhi efek, merusak perkembangan fisik, kesehatan dan kelangsungan hidup (WHO and UNICEF, 2017). Sanitasi dapat diartikan sebagai suatu usaha pencegahan penyakit dengan melenyapkan atau mengendalikan faktor-faktor risiko lingkungan yang merupakan rantai penularan penyakit (Mustikawati, 2013).

Keadaan lingkungan dapat mempengaruhi kondisi kesehatan masyarakat. Banyak aspek kesejahteraan manusia dipengaruhi oleh lingkungan, dan banyak penyakit dapat dimulai, didukung, ditopang atau dirangsang oleh faktor-faktor lingkungan. Kualitas lingkungan yang buruk merupakan penyebab timbulnya berbagai gangguan pada kesehatan masyarakat. Manusia dalam memenuhi kebutuhan hidupnya melakukan aktivitas memproduksi makanan, minuman dan 
barang lain. Selain menghasilkan barang-barang yang akan dikonsumsi, setiap aktivitas yang dilakukan selalu menghasilkan bahan bangunan yang tidak digunakan lagi yang disebut dengan sampah (Kemenlkh, 2016).

Menurut (Adhi et al., 2018) penyakit infeksi kulit banyak ditemukan di kalangan penduduk di daerah beriklim panas, lembap keadaan perorangan yang kurang hygiene, lingkungan yang buruk, pekerja-pekerja yang berhubungan dengan kotoran (misalkan sampah dan selokan) dan pekerja-pekerja yang berhubungan dengan minyak-minyak pelumas. Masyarakat umumnya beranggapan bahwa penyakit kulit bukan penyakit yang membahayakan sehingga tidak perlu penanganan dengan segera jika belum dalam keadaan parah, jika keluhan gangguan kulit tidak dengan cepat ditanggulangi maka lama kelamaan akan menjurus ke arah kulit yang lebih serius (Perdana et al., 2018).

Data Puskesmas Kabil pada bulan April Tahun 2019 menunjukkan bahwa penyakit Alergic Contact Dermatitis termasuk dalam 10 penyakit terbesar yang ada di Puskesmas. Selain itu berdasarkan data yang ditemukan dan pernyataan dari Puskesmas Kabil yang paling banyak mengalami penyakit kulit dari kelurahan kabil. Berdasarkan data yang didapat dari Dinas Lingkungan Hidup Kota Batam diketahui jumlah pemulung yang ada di TPA Telaga Punggur sebanyak 791 Orang, namun jumlah data pemulung tersebut bisa dapat berubah sewaktu-waktu dikarenakan tempat tinggal pemulung yang tidak menetap (Dinas Kesehatan Kota Batam, 2018).

Berdasarkan observasi awal dan wawancara pada Rabu, 06 Maret 2019 di Tempat Pembuangan Akhir (TPA) Telaga Punggur Kelurahan Kabil Kecamatan Nongsa Kota Batam, dari 10 pemulung yang ditemui mereka menghabiskan masa kerja 10 sampai dengan 9 jam (pagi sampai sore) per/hari. Dari 10 pemulung terdapat 6 pemulung yang tidak memperhatikan higiene perorangan (kebersihan kulit, tangan, kaki dan kuku) hal ini dikarenakan pemulung tidak membersihkan diri mereka setelah bekerja, tidak mencuci tangan dan kaki menggunakan air bersih dan sabun setelah bekerja dan tidak memotong kuku dengan rutin.

Dari 10 pemulung terdapat 8 pemulung yang tidak pernah menggunakan Alat Pelindung Diri (APD) saat memulung seperti tidak menggunakan topi, pakaian panjang, sarung tangan dan sepatu boot, dan ada sebagian pemulung yang menggunakan sarung tangan bolong, sarung tangan hasil limbah industri yang di buang di TPA Telaga Punggur, dan rata-rata pemulung menggunakan sepatu berbahan dasar kain tidak menggunakan sepatu boot.

Dari 10 pemulung terdapat 7 pemulung yang mengalami keluhan gangguan kulit. Pada umumnya keluhan gangguan kulit yang dirasakan yaitu timbulnya gatal-gatal apabila mereka mulai berkeringat dan setelah itu timbul kemerahan seperti ruam. Namun tidak sedikit juga ada yang mengalami timbul nanah pada permukaan kulitnya, kemudian ada beberapa di bagian jari pemulung terdapat jamur yang berbentuk hitam pada kuku tangan pemulung. Tujuan penelitian ini untuk mengetahui hubungan higiene perorangan dan karakteristik pemulung dengan penyakit kulit di Tempat Pembuangan Akhir Telaga Punggur Kota Batam.

\section{METODE PENELITIAN}

\section{Jenis Penelitian}

Desain dalam penelitian ini adalah penelitian observasional analitik dengan menggunakan rancangan cross sectional study.

\section{Lokasi dan Waktu Penelitian}

Penelitian ini berlokasi di Tempat Pembuangan Akhir (TPA) Telaga Punggur Kelurahan Kabil Kecamatan Nongsa Kota Batam yang dilaksanakan selama Bulan Mei sampai dengan Juli Tahun 2019.

\section{Populasi dan Sampel}

Populasi penelitian ini adalah pemulung yang terdata dari TPA Telaga Punggur sebanyak 791 pemulung. Dengan menggunakan rumus sampel Slovin, diperoleh sampel sebesar 89 orang. Pemilihan sampel menggunakan non probability sampling dengan teknik purposive sampling.

\section{Pengumpulan Data}

Data dikumpulkan melalui wawancara, observasi dan pemeriksaan. Higiene perorangan didefinisikan sebagai kebersihan yang dilakukan pemulung meliputi kebersihan kulit, tangan, kaki dan kuku. Sedangkan Alat Pelindung Diri (APD) didefinisikan sebagai Alat Pelindung Diri yang digunakan pemulung 
meliputi (topi, pakaian panjang, sarung tangan, dan sepatu boot). Penyakit kulit sendiri definisi operasionalnya adalah ditemukan gejala-gejala pada perubahan kulit pemulung yang merujuk pada penyakit kulit berdasarkan hasil dari pemeriksaan dokter. Untuk variabel dan Alat Pelindung Diri (APD) menggunakan kuesioner sedangkan penyakit kulit menggunakan observasi dan pemeriksaan langsung. Variabel higiene perorangan yang indikatornya terdiri atas kebersihan kulit, tangan, kaki dan kuku. Variabel APD meliputi topi, pakaian panjang, sarung tangan, dan sepatu boot.

Kuesioner diuji validitasnya dengan Korelasi Product Moment dan uji reliabilitas dilakukan dengan Teknik Koefisien Alpha Cronbach. Kuesioner awal berjumlah 30 butir, setelah dilakukan uji validitas hanya 25 butir yang dinyatakan valid dan 5 butir dinyatakan tidak valid. Uji Validitas dan Reliabilitas dilakukan di Zona Pasif TPA Telaga Punggur Batam pada tanggal 13 April 2019 dengan cara menyebar kuesioner untuk 10 responden.

\section{Pengolahan dan Analisis Data}

Pengolahan data yang dilakukan secara statistik dengan menggunakan perangkat lunak komputer SPSS dengan scoring. Pertanyaan positif diberikan skor 3 jika jawabannya benar, sedangkan skor 1 jika jawaban salah. Data yang sudah diinput kemudian diolah dengan analisis univariat dan bivariat.

Uji statistik yang digunakan adalah $C h i$ Square untuk menghubungkan variabel numerik dan kategorik apabila variabel numerik terdistribusi normal. Jika p-value $<0.05$ maka perhitungan secara statistik yang digunakan yaitu Continuity Correction menunjukkan bahwa adanya hubungan antara variabel independen dengan variabel dependen. Analisa data akan dilakukan dengan teknik komputerisasi dengan cara SPSS. Penelitian ini menggunakan taraf signifikan $95 \%$.

\section{HASIL PENELITIAN}

Analisis Univariat

Distribusi frekuensi jenis kelamin pemulung di Tempat Pembuangan Akhir (TPA) Telaga Punggur Kota Batam pada tahun 2019 yaitu $64 \%$ berjenis kelamin perempuan. Dari diagram distribusi umur responden, diperoleh responden terbanyak di kelompok umur dewasa.
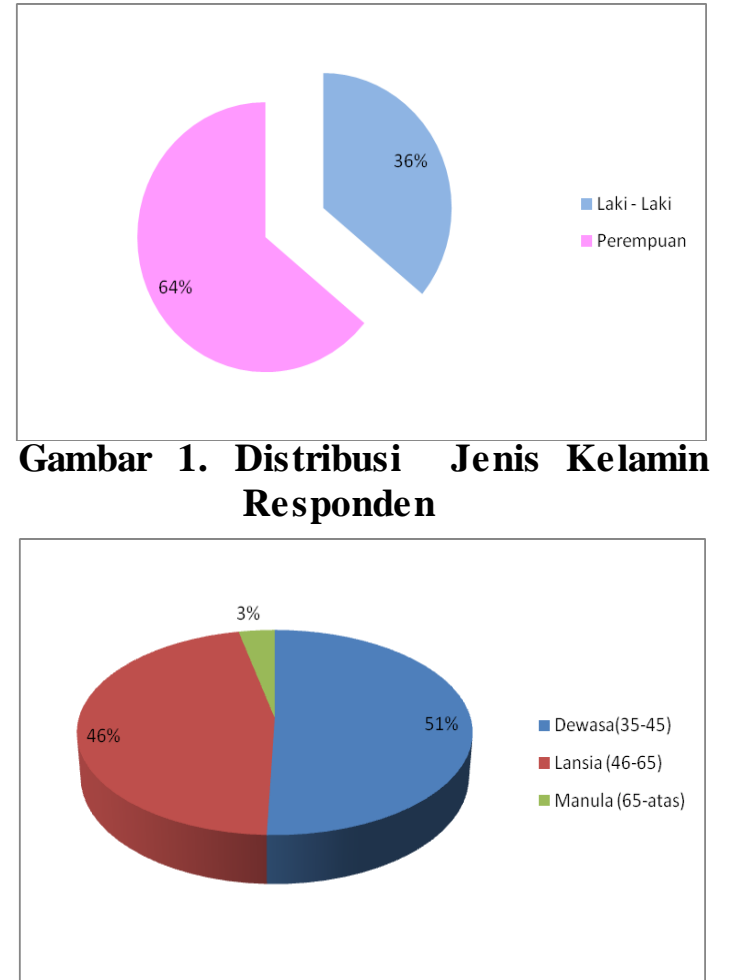

Gambar 2. Distribusi Kelompok Umur Responden

Dari hasil univariat masing-masing variabel diperoleh distribusi seperti tabel berikut.

Tabel 1. Distribusi Frekuensi Variabel Penelitian ( $\mathbf{n = 8 9})$

\begin{tabular}{lcc}
\hline \multicolumn{1}{c}{ Variabel } & n & Persen (\%) \\
\hline Personal Hygiene & & \\
$\quad$ Baik & 22 & 24.7 \\
$\quad$ Buruk & 67 & 75.3 \\
APD & & \\
$\quad$ Memakai & 24 & 27.0 \\
$\quad$ Tidak Pernah & 65 & 73.0 \\
Penyakit Kulit & & \\
$\quad$ Tidak & 26 & 29.2 \\
$\quad$ Ya & 63 & 70.8 \\
\hline
\end{tabular}

Berdasarkan tabel 1 dapat dilihat bahwa sebanyak $67 \quad(75.3 \%)$ responden memiliki higiene perorangan buruk, $73.0 \%$ responden memang tidak pernah menggunakan APD saat melakukan aktifitas memulung serta $70.8 \%$ responden mengalami penyakit kulit.

\section{Analisis Bivariat}

Hasil analisis bivariat dari penelitian ini yaitu tentang Higiene Perorangan dan 
pemakaian APD dengan penyakit kulit pemulung di TPA Telaga Punggur Batam tahun

2019 yaitu sebagai berikut :

Tabel 2. Hasil Analisis Hubungan Higiene Perorangan dan Pemakaian APD dengan Penyakit Kulit ( $=89$ )

\begin{tabular}{lccccc}
\hline \multirow{2}{*}{ Variabel } & \multicolumn{4}{c}{ Kejadian Penyakit Kulit } & \multirow{2}{*}{ p-value } \\
\cline { 2 - 5 } & \multicolumn{3}{c}{ Tidak } & \multicolumn{3}{c}{ Ya } & \\
\cline { 2 - 5 } & $\mathbf{n}$ & \% & n & \% & \\
\hline Personal Hygiene & & & & & \multirow{2}{*}{0.006} \\
$\quad$ Baik & 12 & 54.5 & 10 & 45.5 & \\
$\quad$ Buruk & 14 & 20.9 & 53 & 79.1 & \\
APD & & & & & 0.000 \\
$\quad$ Memakai & 21 & 87.5 & 3 & 12.5 & \\
$\quad$ Tidak Pernah & 5 & 7.7 & 60 & 92.3 & \\
\hline
\end{tabular}

Berdasarkan hasil uji statistik pada tabel 1 di atas menunjukkan bahwa ada hubungan antara Higiene Perorangan dengan penyakit kulit di TPA Telaga Punggur Batam $(p$-value $=0.006)$. Dari 89 responden terdapat 53 (79.1\%) pemulung dalam keadaan higiene perorangan yang buruk mengalami penyakit kulit.

Berdasarkan analisis chi-square pada tabel 1 menunjukkan bahwa ada hubungan antara Pemakaian APD dengan Penyakit Kulit di TPA Telaga Punggur Batam ( $p$ value $=0.000$ ). Dari 89 responden terdapat 60 $(92,3 \%)$ pemulung yang tidak pernah memakai APD mengalami penyakit kulit.

\section{PEMBAHASAN}

\section{Hubungan Higiene Perorangan dengan} Penyakit Kulit pada Pemulung

Hasil analisis Chi Square menunjukkan bahwa ada hubungan signifikan antara Higiene Perorangan dengan Penyakit Kulit di TPA Telaga Punggur Batam, Tahun 2019. Berdasarkan hasil penelitian di lapangan sebagian besar pemulung di TPA Telaga Punggur kurang memperhatikan kesehatan higiene perorangan (kebersihan kulit, tangan, kaki, dan kuku) seperti mencuci tangan tidak menggunakan sabun, kuku tangan dan kaki tidak dalam keadaan pendek dan bersih, memotong kuku pada tangan dan kaki apabila sudah panjang (tidak teratur).

Menurut (Mustikawati, 2013) mencuci tangan dengan air saja lebih umum dilakukan, namun hal ini terbukti tidak efektif dalam menjaga kesehatan dibandingkan dengan mencuci tangan dengan sabun. Penggunaan sabun menjadi efektif karena lemak dan kotoran yang menempel akan terlepas saat tangan di gosok dan bergesek dalam upaya melepasnya. Di dalam lemak dan kotoran yang menempel inilah kuman penyakit hidup (Pratama \& Prasasti, 2018).

Hidup sehat dimulai dari diri sendiri dapat dikatakan bahwa kesehatan yang kita miliki adalah karena upaya kita sendiri maka harus selalu diperhatikan seperti menjaga kebersihan pakaian, memotong kuku, mandi secara teratur, mandi menggunakan air yang bersih dan sabun, serta menjaga kebersihan lingkungan tempat tinggal. Di samping itu, pentingnya peranan pelayanan kesehatan seperti puskesmas untuk memberikan penyuluhan bagi pemulung dalam rangka meningkatkan pengetahuan mengenai perilaku hidup bersih dan sehat sehingga dapat meningkatkan status kesehatan para pemulung (Wulandari \& Wahyudin, 2018).

Menurut

(Srisantyorini

$\&$ Cahyaningsih, 2019) mengabaikan tangan, kaki dan kuku rentan terhadap berbagai macam penyakit infeksi. Kebersihan dimulai dengan mencuci tangan dan kaki menggunakan sabun dan mengeringkannya dengan handuk, menghindari pemakaian sepatu sempit, sedangkan perawatan kuku dilakukan dengan memotong kuku jari tangan dan kaki.

Hasil Penelitian ini sejalan dengan hasil penelitian yang dilakukan (Pratama \& Prasasti, 2018) yang berjudul Hubungan Higiene Perorangan dan Sanitasi Lingkungan dengan Keluhan Penyakit Kulit dengan hasil terdapat hubungan yang bermakna antara kebersihan kulit, tangan, kaki dan kuku dengan $\mathrm{p}=0,009$. 
Hasil penelitian selanjutnya sejalan dengan (Dwi, 2016) yang berjudul Pengaruh Lingkungan TPS, Higiene Perorangan menyatakan bahwa ada hubungan kebersihan kulit dengan keluhan kesehatan salah satunya gangguan kulit pada pemulung dengan $\rho=$ 0,018 .

\section{Hubungan Pemakaian APD dengan Penyakit Kulit pada Pemulung}

Hasil uji statistik yang diperoleh menunjukkan bahwa ada hubungan signifikan antara Pemakaian APD dengan Keluhan Penyakit Kulit di TPA Telaga Punggur Batam, Tahun 2019. Berdasarkan hasil penelitian di lapangan dari 10 pemulung terdapat 8 pemulung yang tidak menggunakan Alat Pelindung Diri (APD) saat memulung seperti tidak menggunakan topi, pakaian panjang, sarung tangan dan sepatu boot, dan ada sebagian pemulung yang menggunakan sarung tangan bolong, sarung tangan hasil limbah industri yang di buang di TPA Telaga Punggur, dan rata-rata pemulung menggunakan sepatu berbahan dasar kain tidak menggunakan sepatu boot.

Berdasarkan teori (Tarwaka, 2012) Alat Pelindung Diri (APD) adalah seperangkat alat keselamatan yang digunakan oleh pekerja untuk melindungi seluruh atau sebagian tubuhnya dari kemungkinan adanya pemaparan potensi bahaya lingkungan kerja terhadap kecelakaan dan penyakit akibat kerja. Menurut (Srisantyorini \& Cahyaningsih, 2019) Penggunaan APD yang rendah merupakan faktor risiko untuk timbulnya penyakit dermatitis kontak akibat kerja.

Hasil penelitian ini sejalan dengan hasil penelitian yang dilakukan (Mustikawati, 2013) menunjukkan bahwa pemakaian alat pelindung diri APD mempunyai hubungan yang signifikan dengan keluhan gangguan kulit dengan $p$ $=0,000$. Hasil penelitian selanjutnya sejalan dengan (Zebua, A.P., Devi, N.S., dan Evi, 2014) menunjukkan bahwa ada hubungan yang signifikan antara Penggunaan APD dengan Gejala Dermatitis Kontak Iritan. Hasil uji statistik yang diperoleh $\rho=0,010$.

\section{KESIMPULAN DAN SARAN}

Higiene perorangan (kebersihan kulit, tangan, kaki dan kuku) Pemulung di TPA Telaga Punggur dari 89 responden terdapat 67 $(75,3 \%)$ pemulung dalam keadaan higiene perorangan yang berkategori buruk. Pemakaian Alat Pelindung Diri (topi, pakaian panjang, sarung tangan, sepatu boot) dari pemulung yang diteliti berjumlah 89 Pemulung TPA Telaga Punggur yaitu terdapat $24(27,0 \%)$ pemulung yang memakai APD dan $65(73,0 \%)$ pemulung yang tidak pernah memakai APD saat bekerja. Berdasarkan hasil dari pemeriksaan dokter Puskesmas Kabil yang dilakukan di TPA Telaga Punggur yaitu dari 89 pemulung ditemukan $63 \quad(70,8 \%)$ pemulung yang mengalami penyakit kulit di TPA Telaga Punggur Kota Batam.

Hasil uji statistik menunjukkan bahwa ada hubungan antara Higiene Perorangan ( $p$ value $=0.006)$ dan Pemakaian APD ( $p$ value $=0.000$ ) dengan penyakit kulit di TPA Telaga Punggur Batam. Sebaiknya pihak pengelola TPA dapat menyediakan sarana dan prasarana untuk membersihkan diri para pemulung setelah melakukan pekerjaan agar tidak terlalu jauh dari lokasi tempat kerja pemulung.

\section{DAFTAR PUSTAKA}

Adhi, D., Aida, S. S. D., Aryani, S., Benny, W. E., Detty, K. D., Emmy, D. S. S., Endi, N., Erdina, P. H., Evita, E. H., Farida, Z., Githa, R., Hanny, N., Herman, C., Made, W. I., Irma, B., Kusmarinah, B., Larissa, P., Lili, L., Lily, S., ... Melani, M. (2018). Ilmu Penyakit Kulit Dan Kelamin. In Fkui.

Dinas Kesehatan Kota Batam. (2018). Profil kesehatan Kota Batam Tahun 2018. Profil Kesehatan Kota Batam. https://doi.org/10.1016/j.ajog.2006.12.01 9

Dwi, K. (2016). Pengaruh Pengetahuan dan Sikap Terhadap Perilaku Higiene Penjamah Makanan di Kantin SMA Muhammadiyah 2 Surabaya. E-Journal Boga, 5(2), 1-7.

Kemenlkh. (2016). Indeks Kualitas Lingkungan Hidup Indonesia 2016. Jakarta: Kementerian Lingkungan Hidup Dan Kehutanan Republik Indonesia. https://doi.org/10.1109/POWERENG.20 09.4915212.

Mustikawati, I. S. (2013). Perilaku Higiene perorangan Pada Pemulung Di TPA Kedaung Wetan Tangerang. Forum Ilmiah Volume, 10(1), 27-35. http://ejurnal.esaunggul.ac.id/index.php/F 
ormil/article/view/821/754.

Perdana, R. S., Putri, D. D., \& Furqon, M. T. (2018). Klasifikasi Penyakit Kulit Pada Manusia Menggunakan Metode Binari Decision Tree Support Vektor Machine (BDTSVM) (Studi Kasus: Puskesmas Dinoyo Kota Malang). Pengembangan Teknologi Informasi Dan Ilmu Komputer.

Pratama, K. F., \& Prasasti, C. I. (2018). Gangguan Kulit Pemulung Di TPA Kenep Ditinjau Dari Aspek Keselamatan Dan Kesehatan Kerja. The Indonesian Journal of Occupational Safety and Health, 6(2), 135. https://doi.org/ 10.20473/ijosh.v6i2.2017.135-145.

Srisantyorini, T., \& Cahyaningsih, N. F. (2019). Analisis Kejadian Penyakit Kulit pada Pemulung di Tempat Pengolahan Sampah Terpadu (TPST) Kelurahan Sumur Batu Kecamatan Bantar Gebang Kota Bekasi. Jurnal Kedokteran Dan Kesehatan. https://doi.org/10.24853/jkk.

\subsubsection{5-147}

Tarwaka. (2012). Ergonomi Indutri. In Ergonomi Industri. https $/ /$ doi.org/ 10.1007/978-1-4684-0104-2_6

WHO and UNICEF. (2017). Progress on Drinking Water, Sanitation and Hygiene: 2017 Update and SDG Baseline. In World Health Organization. https://doi.org/10.1016/j.pnpbp.2017.06.0 16.

Wulandari, K., \& Wahyudin, D. (2018). Sanitasi Rumah Sakit Bahan Ajar Kesehatan Lingkungan. In BPPSDM Kemenkes.

Zebua, A.P., Devi, N.S., dan Evi, N. (2014). Hubungan higiene perorangan dengan keluhan kulit pada pemulung dan fasilitas sanitasi di TPA Terjun kelurahan Terjun kecamatan Medan Marelan tahun 2014. Jurnal Lingkungan Dan Kesehatan Kerja, 1(3), $\quad$ 184-188. https $/ /$ doi.org/ 10.13040/IJPSR.0975-8232.1(3).184-88. 